\title{
Exchanges Rates, Stock Prices and Earning Management: Empirical Evidence of Blue- Chip Companies in Southeast Asia
}

\author{
Meliyanti \\ Sekolah Tinggi Manajemen PPM \\ meliy.thd@gmail.com \\ Martdian Ratna Sari \\ Sekolah Tinggi Manajemen PPM \\ martdianratnasari@gmail.com
}

\begin{abstract}
ABSTRAK
Harga saham merupakan bagian penting dari pendanaan dalam suatu perusahaan. Di sisi lain, komponen ini sangat tergantung pada situasi makro perusahaan yang akan mempengaruhi pengambilan keputusan manajemen. Hal ini menunjukkan bahwa tindakan manajemen dalam mengelola pendapatan perusahaan tidak hanya didasarkan pada sumber internal saja tetapi perlu juga mempertimbangkan dari faktor eksternal. Penelitian ini membahas tentang nilai tukar sebagai faktor eksternal yang dapat memengaruhi tindakan manajemen dalam mengatur pendapatannya. Selain itu, penelitian ini juga bertujuan untuk menganalisis pengaruh nilai tukar dan harga saham terhadap manajemen laba. Populasi dalam penelitian ini adalah perusahaan blue-chip Top Asean Stars dari berbagai sektor industri yang terdaftar dalam Asean Exchanges 2015-2017. Populasi dalam penelitian ini berasal dari 3 negara ASEAN yaitu Indonesia, Malaysia dan Singapura. Hasil penelitian ini menunjukkan bahwa nilai tukar memiliki hubungan positif yang signifikan tehadap manajemen laba. Sedangkan, harga saham tidak memiliki hubungan yang signifikan terhadap manajemen laba. Hal ini juga sesuai dengan hasil penelitian sebelumnya.
\end{abstract}

Kata kunci:

Nilai tukar, Harga saham, Manajemen laba.

\begin{abstract}
Stock prices are an important part of funding in a company. On the other hand, this component is highly dependent on the macroeconomic situation of the company which will influence management decision making. This shows that management actions in managing company revenue are not only based on internal sources but also need to consider external factors. This study discusses the exchange rate as an external factor that can influence management's actions in managing its income. In addition, this study also aims to analyze the effect of exchange rates and stock prices on earnings management. The population in this study is the Top Asean Stars blue-chip companies from various industrial sectors registered in the ASEAN Exchanges 2015-2017. The population in this study came from 3 ASEAN countries, namely Indonesia, Malaysia and Singapore. The results of this study indicate that the exchange rate has a significant positive relationship to earnings management. Meanwhile, stock prices do not have a significant relationship to earnings management. This is also consistent with the results of previous studies
\end{abstract}

Keywords:

Exchange rates, Stock prices, Earnings management. 


\section{INTRODUCTION}

Financial statements are the most fundamental collection of information in decision making by internal and external parties. One of the objectives of financial reports provided to external parties is corporate funding. On the other side, investor's attention to do investing is only centered on the company's profits in the income statement. Company earnings information is assessed as part of financial statements that shows the company's performance (Oei et al., 2008), assist in estimating long-term earnings capabilities in the long term, predicting and estimating risks in investment or funding (Zen and Herman, 2007). Based on their purposes, they can be indicated to manage their earnings. This action is called earning management. Earning management can be done with various methods such as taking a bath, income smoothing, earning maximization and earning minimization.

Earning management is an action how the media also regulators concern about the effects on the quality of reported earnings and capital markets (Fox (1997); Loomis (1999) in
Barton (2001)). Following this argument, the factors that are seen to influence earning managements are coming from capital markets and international trade transaction. According to Subramanyam (2014), earnings can be affected by uncertainty in the return of funds, currencies, political and social conditions and rules or with regard to taxes. So that external factors in international trade transactions such as stock price and exchange rates can certainly be factors that influence earnings management. These factors can affect the company to control or maintain profit stability in transactions. The exchange rate, one of the sensitive factors in international trade (Murtala et al., 2017), will affect the movement of the company's shares and productions in each country. While stock prices move fluctuating, it will affect the company to maintain profit stability, thus giving rise to indications to manage earnings. This does not rule out the possibility of blue-chip companies in Southeast Asia which generally have a goal to maintain the stability of corporate profits.

This research contributes to the accounting, finance and management literature in many ways. First, we are not aware of any 
particular researches which directly examine the association between external factors effect earning management. This research adds the existing researches by providing empirical evidence that external factors can associate with earning management. Furthermore, we use 3 countries (Indonesia, Malaysia and Singapore) in South-Asia (which has the largest population and contributions in ASEAN-5). Whereas, most research examine in Indonesia and use internal factors such as firm size, corporate governance, audit quality and more. Based on previous research, the unavailability and inconsistency of the results that are directly and indirectly related, this research is entitled "Exchange Rates, Stock Prices and Earning Management: Empirical Evidence of Blue-Chip Companies in Southeast Asia".

Problem Formulation in the research, Does the exchange rate associated positively to earning management? Does stock price positively associated with earning management? Benefits of Research, there are several benefits that are expected to be felt by related parties, namely: (1) For the author, as an enhancer of knowledge and sensitivity to international capital markets, especially in
Southeast Asia because it has entered the era of AEC (ASEAN Economic Community); (2) For academics, as one of the contributions in the development of studies, especially in Southeast Asia concerning accounting and capital markets; (3) For further researchers, as an addition to information and research guides with different and more diverse variables; (4) For investors, this research is expected to be useful to provide information in investing.

The remainder of this paper is arranged as follows: the second part is about literature review and hypothesis development, on the third part we examine the methodology in this paper. In forth part, we provide the result and its discussion and for the last part is about conclusion and suggestion.

\section{LITERATURE REVIEW AND} HYPOTHESIS DEVELOPMENT

\section{Agency Theory}

Agency theory is a theory that discusses the agency relationship between principal and agent. Agency relationship is the basis used to understand earnings management. Agency theory arises because of the information asymmetry between the two parties. Agents (management) are parties that are contracted to 
work for the interests of the principal. Therefore, the agent must account for all work well. Jensen and Meckling (1976) mention "Agency relationship as arising where there is a contract under which one or more party (the principals) engages another party (the agent) to perform some service on principal's behalf. Under the contract, the principal delegates some decision-making authority to the agent".

Therefore, agency theory is related to earnings management where this is in conflict with the objectives of both parties which can lead to misappropriation data or information, especially corporate profits.

\section{Exchange Rate}

The exchange rate or known as the exchange rate is an exchange rate agreement on two currencies of each country against payments that occur now or later. The exchange rate of a country's currency can be influenced by many factors, one of which is economic conditions. The instability of this condition is a challenge for business people, especially companies that move directly or indirectly with international trade. If the exchange rate of a country's currency decreases, this will have an impact on the company's stock price traded on the stock exchange. Especially if the company also trades its shares on regional and international stock exchanges. This condition can raise doubts for investors which will have an impact on the decline in stock performance on the stock exchange (Lestari, 2016).

\section{Stock Prices}

Stock prices are prices that are based on changes in the value of shares on the stock exchange and occur at a certain time by the party making an offer or request for shares in the capital market. The high and low stock prices are determined by how many offers or requests made by the seller or buyer. It is also influenced by many external factors such as economic factors. But because this still depends on external factors, the company will try to maintain the value of the company so that it can attract investors. In financial management, the basic concept of a company is to maximize the value of the company. Therefore, stock prices are the focus of the company to get funding from external parties.

According to Brigham and Houston (2013), stock prices can determine shareholder wealth. If the stock price is maximized, the wealth received by shareholders will also be 
maximized. According to Wulandari (2017), active shares can be reflected in a high share price. If the active stock is traded, the dealer will not hold the shares too long to trade. Share prices can also be influenced by many factors both internally and externally. Therefore, investors cannot know for certain that the stock price is up or down. On the other hand, investors can only predict stock prices with trends or historical and other economic factors (Wulandari, 2017).

\section{Earning Management}

Earnings management is a technique or method of an entity to manipulate company profits for the benefit of management. The methods used such as taking a bath, income maximization, income minimization and income smoothing. Earnings management is explained as "intentional management intervention in the process of determining earnings, usually to fulfill personal goals" (Schipper, 1989). Earnings management is considered to be misleading, especially for users of financial statements to assess the economic achievements of the company (Guna and Herawaty, 2010). Therefore, companies tend to do this technique so that it can attract the attention of external parties.

\section{Variable relation and hyphothesis}

The association of exchange rates and earning management

Exchange rate instability will cause price instability from investors (Lestari, 2016). On the other hand, exchange rate is one of the sensitive factors in international trade (Murtala et al., 2017). This statement means, if the firm tends to control the production (mostly for international trade such as import and export activities), it will affect the disclosure of exchange rates in financial statement (Darminto (2008) in Darmawan (2017)). Firm can be indicated control and manage the price and earnings. The level of price changes can affect company profits (Subramanyam, 2014). In the context of increasing corporate profits, exchange rate is one of the factors that affect the changes of profits. Furthermore, if the exchange rate increases, the company has more earning management. Therefore, to increase profits, the company can do earnings management. Based on the literature review and several studies, we hypothesize the following:

H1: Exchange rates positively associated with earning management 
The association of stock price and earning management

In this section, earnings management is carried out not only from internal company factors but also external factors. One of them is the stock price, where the price is reliable company profits. Stock prices continue to fluctuate due to stock trading on the stock exchange. This can reflect the value and performance of the company. Therefore, the company will try to manage the company's profit well by using external parties (Primanita and Setiono, 2006). Based on several studies, it is expected that the increasing of stock price will effect the company to do earning management. Due to maintain information, management can be indicated to make earnings management. Based on the study, we hypothesize the following:

$\mathrm{H} 2$ : Stock price positively associated with earning management

\section{RESEARCH METHODOLOGY}

\section{Sample Selection and data}

Data Analysis Method

The tool used in this research for analytical is multiple linear regressions using SPSS. This test used to determine the interaction between variables which are exchange rates, stock prices and earning management.

\section{Population and Samples}

Population is a unity of subjects at a certain place and time that will be observed with certain qualities (Supardi, 2005). In general, the population is a collection of objects, people or circumstances that have at least one characteristic in common. The population in this study is a financial report published by blue chip companies in ASEAN Exchanges since 2012. While the sample is part of the population that is used as a representative of the population (Supardi, 2005). The sample is part of the population. The sample in this study is a blue-chip company in the Top ASEAN Stars in ASEAN Exchanges are 180 companies. In this study, the sampling technique used purposive sampling method, based on the followingcriteria: (a) The sample is the companies included in the Top ASEAN Stars in ASEAN Exchanges since 2012 and report annual financial reports from 2015-2017; (b) The sample is the company that has complete research data in the 2015-2017 annual period in the study period; and (c) The sample is the 
company's financial statements used are expressed in local currencies.

\section{Collection Data Methods}

According to the time of data collection, the data collected in this study uses time series data. Data collected for 3 consecutive years from 2015 to 2017. Meanwhile, data will be collected in accordance with existing variable data sources as can be seen in table 1 .

\section{Operational Definition and Variable}

\section{Measurement}

The independent variable in this study is the exchange rate with the dependent variable is earnings management and stock prices as intervening variables. Measurement of both independent, dependent and intervening variables in this writing is explained as follows:

\section{a. Exchange Rate}

The exchange rate or exchange rate in this study will be calculated based on the exchange rate of the currency against U.S Dollar (US \$). This is because US \$ is still the basis for calculating the difference in world foreign exchange rates. This exchange rate will be formulated as follows:
Table 1. Collection Data (Sources)

\begin{tabular}{|c|c|}
\hline Variable & Source \\
\hline Exchange Rate & National bank of each country \\
\hline Stock Price & $\begin{array}{c}\text { The respective country stock } \\
\text { exchanges or through } \\
\text { www.aseanexchanges.org. }\end{array}$ \\
\hline $\begin{array}{c}\text { The calculation of the data } \\
\text { collection obtained from the } \\
\text { Management } \\
\text { financial statements of each } \\
\text { country. }\end{array}$ \\
\hline
\end{tabular}

\section{b. Stock Price}

The stock price in this study will be calculated based on the stock price at the closing of the annual period from 20152017. Share price data will be determined based on ASEAN Exchanges.

\section{c. Earning Management}

The calculation of earnings management in this study uses total discretionary accruals in the company's financial statements. To divide discretionary and non-discretionary accruals, the researcher used the Modified Jones Model developed by Dechow in 1995. This model was used by previous researchers and proved to be better at detecting earnings management compared to other models. Calculation of earnings management with Modified Jones 
Model (Dechow, 1995) as follows:

$$
T A_{i t} / A_{i t-1}=\left(N I_{t}-O C F_{t}\right) / A_{i t-1}
$$

NDA (Modified-Jones Model)

$N D A_{t}=\beta_{1}\left(\frac{1}{A_{t-1}}\right)+\beta_{2}\left(\Delta R E V_{t}-\Delta R E C_{t}\right)+\beta_{3}\left(P P E_{t}\right)$

Where:

\begin{tabular}{|c|c|c|}
\hline$T A_{i t}$ & $=$ & Total Accruals \\
\hline$\Delta C A_{t}$ & $=$ & $\begin{array}{l}\text { current assets in } \\
\text { year }_{t} \text { less current assets }\end{array}$ \\
\hline$\Delta C A S H_{t}$ & $=$ & $\begin{array}{l}\text { in } y^{e a r_{t-1}} \\
\text { cash and cash equivalents } \\
\text { in } \text { year }_{t} \text { less cash and } \\
\text { cash equivalents in }\end{array}$ \\
\hline$\Delta C L_{t}$ & $=$ & $\begin{array}{l}\text { year }_{t-1} \\
\text { current liabilities in year } \\
\text { less current liabilities in }\end{array}$ \\
\hline$\triangle S T D E B T_{t}$ & $=$ & $\begin{array}{l}\text { year }_{t-1} \\
\text { short term debt in } \text { year }_{t} \\
\text { less short term debt in } \\
\text { year }_{t-1}\end{array}$ \\
\hline$D E P_{t}$ & $=$ & $\begin{array}{l}\text { year }_{t-1} \\
\text { depreciation and } \\
\text { amortization expense } \\
\text { during year }\end{array}$ \\
\hline $\begin{array}{l}A_{t-1} \\
\Delta R E C_{t}\end{array}$ & $\begin{array}{l}= \\
=\end{array}$ & $\begin{array}{l}\text { total assets in } \text { year }_{t-1} \\
=\text { not receivables in year } \\
\text { less receivables in } \\
\text { year }_{t-1} \text { scaled by total } \\
\text { assets }_{t-1}\end{array}$ \\
\hline
\end{tabular}

\section{Descriptive Statistic}

Descriptive statistics in this study to determine the exchange rate and stock price variables and the dependent variable of earnings management. The measurements used are minimum, maximum, mean (mean) and standard deviation.

\section{Classic Assumption Test}

In this study, there are assumptions that must be met. Those are the normality test, multicollinearity test and heterocedasticity test. Normality Test

Normality test is used to determine whether the data are normally distributed or not (Gani \& Amalia, 2018). Data must be normally distributed because the data can reflect the existing population. If the regression uses abnormal data, then the regression results cannot be generalized to the population. In this study, we used box plot to determine the normality of data.

\section{Multicollinearity Test}

This test aims to test whether the regression model found a correlation between independent variables. A good regression model, if there is no multicollinearity. Multicollinearity can be seen from the value of tolerance and Variance Inflation Factor (VIF) (Gani \& Amalia, 2018). Both of these measurements can show which variables are explained by other independent variables. A common cutoff value that is often used is a tolerance value of less than 0.10 or equal to a VIF value of more than 10. The regression model will say there are no symptoms of 
multicollinearity if the tolerance level is more than 0.10 or equal to a VIF value of less than 10.

\section{Heterocedasticity Test}

Heteroscedasticity test aims to test whether in the regression model there is an unequal variance from the residuals of one observation to another (Gani \& Amalia, 2018). If there is a variance in variance from one observation residual to another, then it is called homoscedasticity. Meanwhile, the opposite will be referred to as heteroscedasticity. A good regression model is one that does not have symptoms of heteroscedasticity or must be homoscedasticity. There are several methods that can be used, one of which is by observing the BreuschPagan test. Testing with the Breusch-Pagan method says if there are no symptoms of heteroscedasticity if the $\mathrm{P}$ value (Prob> chi2) is greater than 0.05 .

Research Design (Moderated Regression Analysis)

The regression analysis in this study, using multiple regression analysis to analyze models and hypothesis. The data that has been collected is then analyzed using the following statistical analysis:
$\mathrm{Y}=\beta+\beta 1 . \mathrm{X} 1+\beta 2 . \mathrm{X} 2+\mathrm{e}$

Where:

$\mathrm{Y}=$ Earning Management

$\beta 1,2=$ each variable coefficient

$\mathrm{X} 1=$ Exchange Rate

$\mathrm{X} 2=$ Stock Prices

$\mathrm{e}=$ error

\section{RESULT AND DISCUSSION}

\section{Results of Sample Selection}

The sampling method used in data collection uses the purposive sampling method, which is the sampling method used in accordance with the research objectives. The result of data processing can be seen in table 2 .

\section{Statistic Descriptive}

This section will be described in the form of a table of data for each variable from 2015 to 2017, which has been processed. The following descriptive statistics table explains the minimum value, maximum value, mean (mean) and standard deviation of each variable.

\section{Classic Assumption Test Result}

Normality Test

In this test, we use box plot graph to see the normality test. Based on the results, there is no data outside the box, so it can be stated that the data is normally distributed. 
Table 2. Result of Sample

\begin{tabular}{|l|c|}
\hline Sample Criteria & Total of Sample \\
\hline $\begin{array}{l}\text { Blue-Chip Companies in } \\
\text { Indonesia, Malaysia and } \\
\text { Singapore based on ASEAN } \\
\text { Exchanges 2014-2017 }\end{array}$ & 270 \\
\hline $\begin{array}{l}\text { Annual Reports are not } \\
\text { provided by the years of } \\
\text { 2014-2017 }\end{array}$ & 0 \\
\hline $\begin{array}{l}\text { Annual Reports are provided } \\
\text { by the years of 2014-2017 }\end{array}$ & 270 \\
\hline $\begin{array}{l}\text { Incomplete data of variables } \\
\text { used in research }\end{array}$ & $(2)$ \\
\hline Foreign Currency & $(45)$ \\
\hline Outlier & $(61)$ \\
\hline Research Sample & 162 \\
\hline
\end{tabular}

Table 3. Statistic Descriptive

\begin{tabular}{|c|c|c|c|c|c|}
\hline Variable & Obs & Mean & $\begin{array}{c}\text { Std. } \\
\text { Dev }\end{array}$ & Min & Max \\
\hline Earn_M & 161 & 81 & $\begin{array}{c}46.620 \\
81\end{array}$ & 1 & 161 \\
\hline Stock_P & 161 & $\begin{array}{c}76.645 \\
96\end{array}$ & $\begin{array}{c}43.598 \\
8\end{array}$ & 1 & 152 \\
\hline Exc_- & 161 & $\begin{array}{c}11.608 \\
7\end{array}$ & $\begin{array}{c}6.0168 \\
24\end{array}$ & 1 & 23 \\
Rate & & & \\
\hline
\end{tabular}

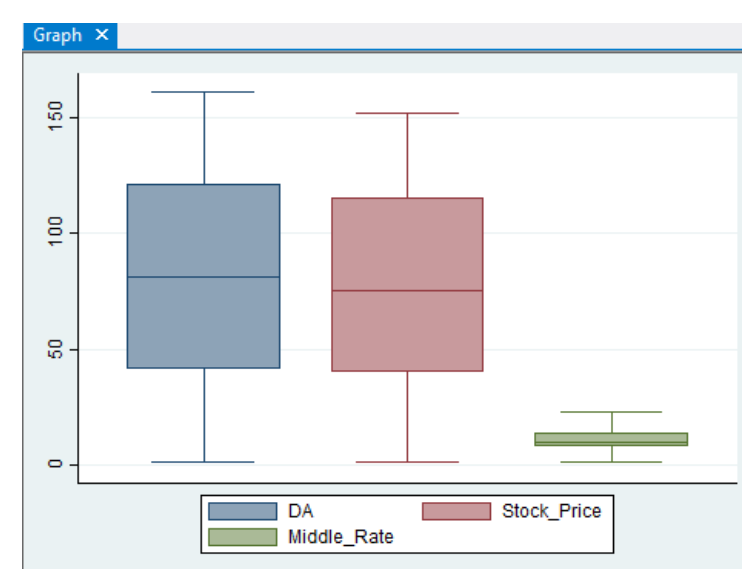

Picture 1. Box Plot Graph

Mulitcollonierity Test

In the table 4, it can be seen that the VIF value of each variable to earning management as an independent variable is less than 10 and the value of $1 /$ VIF is more than 0.10 . Then it can be concluded that there is no multicollinearity.
Table 4. Multicollonierity Test Result

\begin{tabular}{|c|c|c|}
\hline Variable & VIF & 1/VIF \\
\hline Exc_Rate & 1.00 & 0.995875 \\
\hline Stock_P & 1.00 & 0.995875 \\
\hline
\end{tabular}

Estat hottest

Breusch-Pagan / Cook-Weisberg test for heteroscedasticity

Ho: Constant variance

Variables: fitted values of Earn_M

$\operatorname{chi2}(1) \quad=0.75$

Prob $>$ chi $2 \quad=0.3861$

\section{Picture 2. Heterocedasticity Test Result}

\section{Heteroscedasticity Test}

In the results of this test it can be seen that the p-value of 0.3861 which is greater than 0.05. It can be concluded that the regression model is free from heteroscedasticity symptoms.

\section{Regression Analysis}

In this study we use an analysis of multiple linear regression between the exchange rate and stock price variables and the earning management variable as the dependent variable. The results of research using STATA 14.2 software are can be seen in table 5 . 
Table 5. Regression Linier Analysis Result

\begin{tabular}{|c|c|c|c|c|}
\hline Variable & Coeff. & Std. Err. & $\mathbf{t}$ & $\mathbf{P}>|\mathbf{t}|$ \\
\hline Stock_P & - & 0.083234 & - & 0.162 \\
& 0.1169911 & & 1.41 & \\
\hline Exc_Rate & 1.49842 & 0.6031256 & 2.48 & 0.014 \\
\hline cons & 72.57218 & 9.849636 & 7.37 & 0.000 \\
\hline \multicolumn{5}{|c|}{ Obs. 161, Adj R-Squared $=0.0346(3.46 \%)$, Prob > } \\
F=0.0230
\end{tabular}

a. The F test is used to test whether the model used in the study is feasible or not. If the Prob > F value is less than 0.05 then the $\mathrm{F}$ test accepts $\mathrm{H} 1$ at a significance level of $5 \%$ or that means all the independent variables simultaneously have a significant effect on the dependent variable. Based on the regression results, the $\mathrm{F}$ test value is 0.0165. So it can be concluded that the variables Stock_P and Exc_Rate simultaneously have a significant influence on earnings management (Earn_M).

b. The coefficient of determination is used to find out how simultaneously the ability of the dependent variable in explaining the independent variable. The value of determination is determined by the value of R-squared. It can be seen that the R-Squared value is 0.0346 which means that all independent variables can explain the
Earn_M variable of $3.46 \%$. Then the remaining amount $96.54 \%$ is influenced by other variables outside the regression model.

c. This hypothesis test refers to the level of significance of the independent variable with partial t test. It can be said to be significant if $\mathrm{P}>(\mathrm{t})$ or also called $\mathrm{p}$ value or significance of less than 0.05 . In column $\mathrm{P}>(\mathrm{t})$ it is explained that the level of the Stock_P variable is 0.162 . This value is more than 0.05 . Therefore it can be concluded that the Stock_P variable does not have a significant positive relationship to the Earn_M variable.

d. In column $P>(t)$ it is explained that the level of the Exc_Rate variable is 0.014 . This value is less than 0.05 . Therefore it can be concluded that the Exc_Rate variable has a significant positive relationship to the Earn_M variable.

\section{Discussion of the result}

Exchange rates positively associated with earning management

Based on several studies that indirectly stated that currencies can be one of the factors of earning management. In this study, the 
results were obtained even there has not been exist in previous research because researchers used different variables. Other things can also happen due to the use of different currencies in each country. In addition, it can be because transaction activities using foreign currencies in each company in each industry are very different and varied. In this study also uses company data from 3 countries that have different industrial characteristics.

Stock Price is not positively associated with earning management

The results of the study indicate that there is no significant relationship between stock prices with earnings management actions. This result is consistent with previous research which revealed that there was no significant effect between stock prices and income smoothing actions (Zen and Herman, 2007). This can be due to earnings management actions will have more influence on stock returns than stock prices as stated in other studies.

\section{CONCLUSION AND}

\section{RECOMMENDATION}

Our paper contributes to the literature by studying the stock price and currencies in the period of 2015 - 2017, using ASEAN
Exchange. We provide results based on the sample consisting of non-financial companies listed in ASEAN Exchange (Blue-Chip Companies that include in Top ASEAN Stars in Indonesia, Malaysia and Singapore). For the reason, conclusion concern only for ASEAN (Indonesia, Malaysia and Singapore's Top ASEAN Star Companies) without generalizing to the other context.

In general, our research provide empirical and theoretical knowledge also add to recent literature on earning management, using modified Jones-Model method, which is studied by many researchers. This research also aligned with income smoothing context. This statement reflects the results of one hypothesis. We stated that exchange rates positively associated with earning management, while stock price did not. This result is consistent with previous research which provide about income smoothing instead of earning management.

Among the limitations of this study is the short period, so it is possible to take over a longer time. Due to time constraints, researchers only conducted research for 3 periods and only from 3 countries. So that it is less able to represent the entire expected 
population for Southeast Asia. A comparison between each countries, could be made. On the other hand, next researchers can use the difference of measuring earning managements. For the last, our study finds a positive relationship between exchange rates and earning management, but we do not look into the mechanism behind the relationship. For future research, it is expected to consider using the companies as research population. It is because companies have different type of characteristics and also the international transactions. It is expected also to consider between countries because of the differences economic environment. Also, next research is expected to extend the research period so can get more accurate conclusions which can be more describe the variables. 
Exchanges Rates, Stock Prices and Earning..... (Meliyanti \& Martdian Ratna Sari)

\section{REFERENCES}

Barton, J. (2001). Does the use of financial derivatives affect earnings management decisions? Accounting Review, 76(1), 1-26. https://doi.org/10.2308/accr.2001.76.1.1

Darmawan, S. (2017). Analisis pengaruh corporate governance, variabel ekonomi makro terhadap financial distress dengan variabel kontrol ukuran perusahaan dan jenis kepemilikan. Efektif Jurnal Ekonomi dan Bisnis

EF Brigham, JF Houston. (2013). Fundamental of Financial Management 13th. Ohio: South Western

Gunawan, Jeffrey Lingga. (2017). Pengaruh Inflasi, Suku Bunga Sbi, Pdb Dan Nilai Tukar Terhadap Indeks Harga Saham Gabungan (IHSG) Di Bursa Efek Indonesia Tahun 2000-2014. Indonesia: Universitas MaChung

Hartono, Jogianto. (1998). Teori Portofolio dan Analisis Investasr, Edisi Pertama, PT.BPFE. Yogyakarta

Hermawan. (1999). Analisis Faktor-faktor yang Berasosiasi dengan Prilaku Income Smoothing oleh Perusahaan Publik yang Terdaftar di Bursa Efek Jakarta. Indonesia, Yogyakarta.

Jensen, M. C., \& Meckling, W. H. (1976). Theory of the firm: Managerial behavior, agency costs and ownership structure. Journal of Financial Economics, 3(4), 305-360.

Lestari, Mia Puji. (2016). Pengaruh Faktor Internal dan Faktor Eksternal terhadap Harga Saham Perusahaan Pada Indeks LQ45. Indonesia, Surabaya: Jurnal Ilmu Mnajamenen, Fakultas Ekonomi Universitas Negeri Surabaya

Murtala, Masbar, R., Fajri, \& Nasir, M. (2017). Fluctuation Analysis of Rupiah Exchange Rate of Dollar United States in Indonesia. European Journal of Agricultre and Forestry Research, 5(6), $37-50$.

Oei, R., Ramsay, A., \& Mather, P. (2008). Earnings persistence, accruals and managerial share ownership. Accounting and Finance, 48, 475-502.

Primanita dan Setiono. (2006). Manajemen Laba: Konsep, Bukti Empiris dan Implikasinya. Indonesia: Jurnal Ekonomi, Sinergi Vol.8 No.1

Subramanyam, K.R. (2014). Financial Statement Analysis, eleventh edition. Singapore: McGraw-Hill Education 
Journal of Management Vol. 16, No. 2, $2019: 208-222$

Zen, Sri Daryanti dan Herman, Merry. (2007). Pengaruh Harga Saham, Umur Perusahaan, dan Rasio Profitabilitas Perusahaan Terhadap Tindakan Perataan Laba Yang Dilakukan Oleh Perusahaan Perbankan Yang Terdaftar Di Bursa Efek Jakarta. Indonesia: Jurnal Akuntansi dan Manajemen Vol.2 No.2 Desember 